\title{
Diagnosing Cervical Fusion: A Comprehensive Literature Review
}

\author{
Nanin Sethi ${ }^{\star}$, James Devney ${ }^{\dagger}$, Holly L. Steiner $^{\ddagger}$, K. Daniel Riew ${ }^{\ddagger}$ \\ ${ }^{*}$ Potomac Valley Orthopaedic Associates, ${ }^{\dagger}$ Nebraska Spine Center, \\ ${ }^{*}$ Washington University Medical College, USA
}

\begin{abstract}
Study Design: Comprehensive literature review.
Purpose: To document the criteria for fusion utilized in these studies to determine if a consensus on the definition of a solid fusion exists.

Overview of Literature: Numerous studies have reported on fusion rates following anterior cervical arthrodesis. There is a wide discrepancy in the fusion rates in these studies. While factors such as graft type,

Instrumentation, and technique play a factor in fusion rate, another reason for the difference may be a result of differences in the definition of fusion following anterior cervical spine surgery.

Methods: A comprehensive English Medline literature review from 1966 to 2004 using the key words "anterior," "cervical," and "fusion" was performed. We divided these into two groups: newer studies done between 2000 and 2004, and earlier studies done between 1966 and 2000. These articles were then analyzed for the number of patients, follow-up period, graft type, and levels fused. Moreover, all of the articles were examined for their definition of fusion along with their fusion rate. Results: In the earlier studies from 1966 to 2000, there was no consensus for what constituted a solid fusion. Only fifteen percent of these studies employed the most stringent definition of a solid fusion which was the presence of bridging bone and the absence of motion on flexion and extension radiographs. On the other hand, the later studies (2000 to 2004) used such a definition a majority (63\%) of the time, suggesting that a consensus opinion for the definition of fusion is beginning to form.
\end{abstract}

Conclusions: Our study suggests that over the past several years, a consensus definition of fusion is beginning to form. However, a large percentage of studies are still being published without using stringent fusion criteria. To that end, we recommend that all studies reporting on fusion rates use the most stringent criteria for solid fusion following anterior cervical spine surgery: the absence of motion on flexion/extension views and presence of bridging trabeculae on lateral x-rays. We believe that a universal adoption of such uniform criteria will help to standardize such studies and make it more possible to compare one study with another.

Key Words: Cervical, Fusion, Arthrodesis, Ppseudoarthrosis

\section{Introduction}

Although there have been numerous studies regarding fusion rates following anterior cervical arthrodesis, there is a paucity of long-term data on the effect of fusion status on clinical outcome. In order to perform prospective outcome studies, there must first be a uniform consensus about what constitutes a solid fusion. While discrepancies in the fusion rates among various studies may be due to factors such as graft type, instrumentation, and surgical technique, an equally important factor may be the criterion used to assess

Received Aug 25, 2008; accepted Sep 15, 2008

Corresponding author: K. Daniel Riew, MD

11300 One Barnes-Jewish Hospital Plaza, Washington University School of Medicine

St. Louis, MO 63110, USA

Tel: +1-314-747-2565, Fax: +1-314-747-2599, E-mail: riewd@wustl.edu

Copyright (C) 2008 by Korean Society of Spine Surgery

This is an Open Access article distributed under the terms of the Creative Commons Attribution Non-Commercial License (http://creativecommons.org/licenses/by-nc/3.0) which permits unrestricted non-commercial use, distribution, and reproduction in any medium, provided the original work is properly cited.

Asian Spine Journal • pISSN 1976-1902 eISSN 1976-7846 
the status of fusion. Variations in such a criterion may in part explain the wide variety of fusion rates reported in the literature. We undertook the present study to determine if there is a consensus opinion in the literature regarding the best methodology for the assessment of fusion status following an anterior cervical arthrodesis procedure.

\section{Materials and Methods}

A literature search was performed on Medline from 1966 to June, 2004. The key words entered were anterior, cervical, and fusion with the search limited to articles in the English language and human subjects. A total of 604 articles were selected by Medline. We divided these into two segments: the newer articles from 2000 2004 and the older articles from 1966 2000. These articles were then investigated as to their relevance to spine related procedures in which the authors reported on their results following anterior cervical procedures. All case reports were excluded as were articles dealing with circumferential fusion. One hundred and forty-four articles were selected due to their relevance to our study. These articles were analyzed as to the number of patients, their ages, follow-up period, graft type, diagnosis, and number of levels fused. Moreover, all of the articles were then examined for their definition of fusion along with their rate of fusion.

Tables 1 and 2 present the information obtained from each segment (prior to 2000 and 2000-2004) reviewed.

\section{Results}

One hundred and twelve articles from 1966 to 2000 reported on a combined total of 8,073 patients $^{1-112}$. Most studies included a breakdown of the number of levels fused. However, for 967 patients the number of levels fused could not be determined. There were 3,692 one-level fusions, 2317 two-level fusions, 906 three-level fusions, 177 fourlevel fusions and fourteen five-level or greater fusions. The follow up period ranged from six months to nine years. Fusion rates in the studies varied from a low of nine percent to one hundred percent. The definition of fusion was highly variable amongst the studies. The most stringent definition of a solid fusion was spanning trabeculae across the graft/host interface AND the absence of motion on flexion/extension lateral cervical spine radiographs. Such criteria were noted in only fifteen percent of the articles (17/112). Thirty percent of the articles (34/112) considered the presence of EITHER spanning trabeculae across the graft/host surface OR the absence of motion on flexion/extension radiographs as adequate for determining successful fusion. Eighteen percent of the articles (20/112) based their definition of a solid fusion SOLELY on the presence of spanning trabeculae, while nine percent $(10 / 112)$ of the articles based their criteria SOLELY on the absence of motion on flexion/extension lateral radiographs. The vast majority of studies gave no criteria for their definition of a solid fusion (61/112). Some studies based their arthrodesis rate solely on clinical grounds. Four of the studies used CT scans along with plain radiographs and one study used MRI to diagnose fusion. In addition, many of the studies examining fusion rates did not take post-operative radiographs on their entire sample but still managed to determine fusion rates.

Thirty two articles from 2000 to 2004 reported on a total of 3,006 patients ${ }^{13-144}$. There were 767 one-level fusions, 765 two-level fusions, 270 three-level fusions, twenty-two four-level fusions, and 1,182 patients whose operated levels were unknown. Follow up periods ranged from a few months to several years. Fusion rates ranged from sixty nine percent to one hundred percent. The more recent articles (2000-2004) were more particular about including their definition of fusion as only one study failed to report their definition of fusion. The most stringent definition of solid arthrodesis which was the presence of spanning trabeculae and absence of motion on flexion/extension cervical spine radiographs was used by sixty-three percent of the articles (20/32). Thirty-eight percent (12/32) considered EITHER the presence of spanning trabeculae OR the absence of motion on flexion/extension radiographs as adequate for determining successful fusion. Eleven of the thirty-two articles based their definition SOLELY on the presence of spanning trabeculae while one of the studies SOLELY looked at dynamic films. With regards to flexion/extension radiographs, however, there was discrepancy with respect to the amount of motion that was acceptable to deem a fusion solid. Some articles based their fusion rate on no motion, while others would accept $2^{\circ}$ of angular motion and some would accept $4^{\circ}$ of angular motion. Five of the articles gave their own classification system for fusion. 
Table 1. Literature review data from 1996 to 2000 study

\begin{tabular}{|c|c|c|c|c|c|c|c|c|}
\hline & Author & Journal & $\begin{array}{l}\text { Number of } \\
\text { patients }\end{array}$ & Age & Follow-up & Graft type & Criteria & Fusion rate \\
\hline 1. & Wetzel FT & Yale J Biology Med & 32 & 49.0 & 19.0 & Fibular all & $\mathrm{St}$ & 65.0 \\
\hline 2. & Mutoh N & Int Orthop & 433 & 52.4 & 27.2 & $\begin{array}{l}\text { Ilica377 } \\
\text { Fibula66 }\end{array}$ & $\begin{array}{l}\text { Fe and } \\
\text { Tomograph }\end{array}$ & 96.6 \\
\hline 3. & Baba H & Paraplegia & 92 & 47.0 & 8.5 & Icbg & Solid bony union & 95.0 \\
\hline 4. & Ebrahein N & Orthopedics & 25 & 48.9 & 31.2 & Icbg all plated & $\begin{array}{l}\text { Stability on } \\
\text { Fleion/extension; } \\
\text { Agsence fo local pa } \\
\text { Bony incorporation }\end{array}$ & $\begin{array}{l}100.0 \\
\text { ain; }\end{array}$ \\
\hline 5. & Isu $\mathrm{T}$ & Neurosurgery & 40 & 55.0 & 36.0 & Local bone & None & 100.0 \\
\hline 6. & Katsura A & J Spinal Disord & 44 & 56.1 & 17.35 & Auto icbg plated & None & 96.0 \\
\hline 7. & Seifert V & Neurosurgery & 22 & 53.0 & 21.0 & Icbg & None & 100.0 \\
\hline 8. & Shapiro S & Surg Neurol & 195 & 0 & 40.30 & All fibu all plated & None & 100.0 \\
\hline 9. & Deburg A & J Bone Joint Surg Br & 8 & 71.0 & 1.0 to 7.0 & & None & 100.0 \\
\hline 10. & Zdeblick TA & J Bone Joint Surg Am & 35 & 50.0 & 44.0 & Auto icbg/Fibula & St and no motion & 97.0 \\
\hline 11. & Tominaga $\mathrm{T}$ & Surg Neurol & 12 & 55.8 & 13.0 & Icbg all plated & None & 100.0 \\
\hline 12. & Shapiro S & Neurosurgery & 88 & 52.0 & 22.0 & All fibula plated & $\mathrm{Fe}$ & 100.0 \\
\hline 13. & Johnston F & Neurosurgery & 32 & 54.0 & 9.6 & Icbg plated & None & 100.0 \\
\hline 14. & Herman J & Neurosurgery & 20 & & 28.0 & Icbg 95 Allo 5 per & None & 100.0 \\
\hline 15. & Isu $\mathrm{T}$ & Neurosurgery & 90 & 51.0 & 24.0 & Icbg & None & 100.0 \\
\hline 16. & MacDonald R & Neurosurgery & 36 & 58.0 & 31.0 & All fibula15 unstr & $\begin{array}{l}\text { Bony Bridging } \\
\text { No instability }\end{array}$ & 97.0 \\
\hline 17. & Coric D & Neurosurgery & 18 & 49.1 & 22.4 & Allo icbg stplated & St gm dep & 100.0 \\
\hline 18. & Bishop R & Neurosurgery & 132 & 0 & 31.0 & Allo and auto icbg & St & \\
\hline 19. & Connoll PJ & J Spinal Disord & 43 & 0 & 16.5 & $\begin{array}{l}\text { Auto icbg } \\
25 \text { plated }\end{array}$ & St & $\begin{array}{r}100.0 \\
83.0\end{array}$ \\
\hline 20. & Goffin J & $\mathrm{J}$ of Spinal Disorder & 25 & 32.7 & 1.0 to 10.0 & All plated & None & 100.0 \\
\hline 21. & McGuire R & J Spinal Disord & 6 & & $2.0+$ & Icbg & St & 66.0 \\
\hline 22. & Chang K & J Spinal Disord & 27 & 49.0 & 12.0 to 24.0 & Icbg & None & 100.0 \\
\hline 23. & Iwaski M & Int Orthop & 4 & 54.0 & 5.5 & Icbg & None & 100.0 \\
\hline 24. & Naito M & Int Orthop & 106 & 55.0 & 4.5 & Icbg & None & 97.0 \\
\hline 25. & Housh G & Neurosurgery & 19 & 47.6 & 15 & Auto/allo fib+icbg & None & 100.0 \\
\hline 26. & Kadoya S & Neurosurgery & 19 & 56.0 & 38.0 & Icbg & None & 89.0 \\
\hline 27. & Aronson N & Neurosurgery & 86 & 48.0 & 0 & Icbg & St and fe & 96.0 \\
\hline 28. & Connoly E & & 63 & 47.0 & 373.0 & & $\mathrm{Bt}$ & 79.0 \\
\hline 29. & Siqueira $\mathrm{E}$ & Surg Neurol & 221 & 52.0 & 0 & Calf bone & None & 100.0 \\
\hline 30. & Zhang Z & Spine & 121 & 50.0 & 22.0 & $\begin{array}{l}\text { Auto } 83 \\
\text { Allo } 38\end{array}$ & None & $\begin{array}{r}\text { Aut } 84.30 \\
\text { All } 50.0\end{array}$ \\
\hline 31. & Kadoya S & Spine & 33 & 55.0 & 34.0 & Icbg & None & 94.0 \\
\hline 32. & Mann DC & Paraplegia & 16 & 26.0 & 10.0 & Icbg plated & None & 100.0 \\
\hline 33. & Kostuik J & Spine & 42 & 4730 & 0 & Icbg plated & None & 100.0 \\
\hline 34. & Casper W & J Spinal Disord & 356 & 45.0 & 1.0 to 9.0 & $\begin{array}{l}\text { Auto } 259 \text { allo } 97 \\
\text { Plated } 146 \text { non pl } 210\end{array}$ & None & 96.0 \\
\hline 35. & Yangjia $\mathrm{O}$ & Spine & 15 & 45.6 & 93.0 & Icbg & None Ct Mri Xray & 100.0 \\
\hline 36. & Ripa D & Spine & 92 & 34.3 & 19.3 & Icbg plated & Sst and fe & 99.0 \\
\hline 37. & Clements D & Spine & 94 & 46.0 & None & Icbg & $\mathrm{Fe}$ & 97.0 \\
\hline 38. & Muhlbauer M & Acta Neurochir & 42 & 47.0 & 10.7 & Icbg plated & None & 100.0 \\
\hline 39. & Krag M & J Spinal Disord & 92 & 45.0 & 8.5 & Icbg & $\mathrm{St}(60) \mathrm{Fe}(89)$ & \\
\hline 40. & Savolainen S & Acta Neurochir & 250 & 48.0 & 6.0 & $\begin{array}{l}\text { Auto } 149 \\
\text { Allo } 104\end{array}$ & Dep & 98.0 \\
\hline 41. & Matge G & Acta Neurochir & 80 & 0 & 20. to 26.0 & Local with bak cage & Fe with $<4$ deg & 100.0 \\
\hline 42. & Moerman J & Acta Orthop Belg & 22 & 41.0 & $1.0+$ & Icbg plated & None & 100.0 \\
\hline
\end{tabular}


Table 1. Literature review data from 1996 to 2000 study

\begin{tabular}{|c|c|c|c|c|c|c|c|c|}
\hline & Author & Journal & $\begin{array}{l}\text { Number } \\
\text { patients }\end{array}$ & Age & Follow-up & Graft type & Criteria & Fusion rate \\
\hline 43. & Schnee C & Spine & 142 & 48.1 & 8.1 & Icbg some plated & St & 96.7 \\
\hline 44. & Phillips F & Spine & 16 & 47.0 & 32.0 & Icbg & St and Fe with $<2 \mathrm{~mm}$ & 88.0 \\
\hline 45. & Hilibrand A & Spine & 38 & 0 & 68.0 & Icbg fibula & $\begin{array}{l}\mathrm{Fe}>2 \mathrm{~mm} \\
\text { Or lucency }\end{array}$ & 76.0 \\
\hline 46. & Malca S & Spine & 52 & 34.0 & 7.4 & Xenograft plated & St Fe with zero moti & 100.0 \\
\hline 47. & Lowery G & Spine & 20 & 47.0 & 28.0 & $\begin{array}{l}\text { Auto } 35 \% \text { plated } \\
\text { Allo } 65 \%\end{array}$ & $\mathrm{St}$ or $\mathrm{Fe}>2 \mathrm{~mm}$ & 45.0 \\
\hline 48. & An $\mathrm{H}$ & Spine & 77 & $\begin{array}{r}\text { Aut } 46.1 \\
\text { All } 48.0\end{array}$ & $\begin{array}{r}\text { Aut } 18.4 \\
\text { All } 17.5\end{array}$ & Both & $\mathrm{St}$ and $\mathrm{Fe}$ & $\begin{array}{l}\text { Aut } 73.7 \\
\text { All } 53.8\end{array}$ \\
\hline 49. & Bringham C & Spine & 43 & 48.0 & 14.0 & Icbg & St and $\mathrm{Fe}$ & 93.0 \\
\hline 50. & Villas C & Acta Orthop Scand & 21 & 54.0 & 36.0 & Icbg 9 plated & St and $\mathrm{Fe}$ & 95.0 \\
\hline 51. & Cauthen $\mathrm{J}$ & Spine & 348 & 40.0 & 62.0 & $\begin{array}{l}\text { Auto } 30 \% \\
\text { Allo } 70 \%\end{array}$ & $\mathrm{Fe}$ & 83.0 \\
\hline 52. & Emery $\mathrm{S}$ & Spine & 16 & 59.0 & 37.0 & Icbg & St and $\mathrm{Fe}$ & 56.0 \\
\hline 53. & Walters W & Spine & 64 & 46.0 & 73.0 & Icbg & $\mathrm{Fe}$ and st (assumed) & 90.0 \\
\hline 54. & Emery $\mathrm{S}$ & Spine & 29 & 47.0 & 28.30 & & St and $\mathrm{Fe}$ & 95.6 \\
\hline 55. & Capen D & Clin Orthop Relat Res & 88 & 27.0 & 44.0 & Fibul 85 icbg 3 & None & 100.0 \\
\hline 56. & Doi K & Spine & 6 & 54.5 & 26.0 & Vascularizedfibula & None & 100.0 \\
\hline 57. & Herkowitz H & Spine & 18 & 58.4 & $2.0+$ & Icbg & St and $\mathrm{Fe}$ & 63.0 \\
\hline 58. & Brown $\mathrm{J}$ & Spine & 10 & 45.0 & 15.0 & Icbg 10 fib 3 & $\begin{array}{l}\text { St or Fe or } \\
\text { absence of pain }\end{array}$ & 100.0 \\
\hline 59. & Gore D & Spine & 146 & 48.0 & 5.0 & Icbg & None & 97.0 \\
\hline 60. & Zdeblick TA & JBJS & 14 & 45.7 & 28.0 & 8 fibula 6 icbg & $\begin{array}{l}\text { St and } \mathrm{Fe} \\
\text { and tomograms }\end{array}$ & 100.0 \\
\hline 61. & Laus L & & 11 & 45.0 & None & Icbg plated & None & 100.0 \\
\hline 62. & Jacobs B & JAMA & 65 & 30.0 to 59.0 & 38.0 & Notmentioned & None & 98.5 \\
\hline 63. & Anderson L & J Trauma & 16 & 32.8 & None & Tibia & None & 100.0 \\
\hline 64. & Tunturi $\mathrm{T}$ & Arch Orthop Traumat & 29 & 43.0 & Yrs 6.5 & Icbg & None & 100.0 \\
\hline 65. & Depalure A & Clin Orthop Relat Res & s 146 & $\begin{array}{r}17.0 \text { to } \\
62.0\end{array}$ & 27.4 & None & $\mathrm{Fe}$ & 89.1 \\
\hline 66. & Brown M & Clin Orthop Relat Res & 98 & None & None & 53 all 45 auto & St & 96.0 \\
\hline 67. & Fielding $\mathbf{J}$ & Clin Orthop Relat Res & 3 & 47.0 & None & Icbg & None & 100.0 \\
\hline 68. & Kambin P & Clin Orthop Relat Res & 93 & None & $2.0+$ & Icbg & $\begin{array}{l}\text { Fe and } \\
\text { New bone formation }\end{array}$ & 99.0 \\
\hline 69. & Gore D & Clin Orthop Relat Res & 58 & 47.0 & $1.0+$ & $\begin{array}{l}\text { Tibia } 37 \\
\text { Fibula } 21\end{array}$ & $\mathrm{St}$ or $\mathrm{Fe}$ & 100.0 \\
\hline 70. & Brunton F & J Bone Joint Surg Br & 75 & $\begin{array}{r}20.0 \text { to } \\
73.0\end{array}$ & $4.5 \mathrm{yrs}$ & Icbg & None & 77.0 \\
\hline 71. & Simmons & J Bone Joint Surg Br & 84 & $\begin{array}{r}20.0 \text { to } \\
70.0\end{array}$ & 34.0 & Icbg & None & 96.0 \\
\hline 72. & Tippets R & Neurosurgery & 28 & 39.9 & 4.9 & Icbg plated & None & 100.0 \\
\hline 73. & Kojima t & Neurosurgery & 45 & 55.0 & None & Icbg & None & 100.0 \\
\hline 74. & Young W & Spine & 23 & 35.0 & 6.0 & Fib all & St & 92.0 \\
\hline 75. & Brodke D & Spine & 51 & 45.0 & 12.0 & Icbg & $\begin{array}{l}\text { St and Fe } \\
\text { With no motion }\end{array}$ & 94.0 \\
\hline 76. & Brodsky A & Spine & 17 & 49.8 & 60.0 & Icbg & $\begin{array}{l}\text { St dissol of end plates } \\
\text { Evidence of remodeling }\end{array}$ & ng 94.0 \\
\hline 77. & Zdeblick TA & Spine & 87 & 43.0 & 28.0 & All 27 auto 60 & $\mathrm{St}$ & 87.0 \\
\hline 78. & Grossman W & Spine & 50 & 53.0 & 22.1 & Fib all & One end plate fusion & 100.0 \\
\hline 79. & Suh P & Spine & 13 & 43.0 & 13.0 & Icbg plated & St & 100.0 \\
\hline 80. & Kozak J & J Spinal Disord & 40 & 44.0 & 15.0 & Icbg & St & 87.5 \\
\hline
\end{tabular}


Table 1. Literature review data from 1996 to 2000 study

\begin{tabular}{|c|c|c|c|c|c|c|c|c|}
\hline & Author & Journal & $\begin{array}{l}\text { Number of } \\
\text { patients }\end{array}$ & Age & Follow-up & Graft type & Criteria & Fusion rate \\
\hline 81. & Shinomiya K & J Spinal Disord & 443 & 52.4 & None & $\begin{array}{l}\text { Ilium } 377 \\
\text { Fibula } 66\end{array}$ & None & 96.6 \\
\hline 82. & Lindberg L & Acta Orthop Scand & 20 & 47.0 & 18.8 & Icbg & None & 100.0 \\
\hline 83. & Svengaard N & Acta Neurochir & 24 & 32.0 & None & Tibial & None & 100.0 \\
\hline 84. & White A & & 65 & 53.8 & 3.25 & Icbg & St or Fe & 74.0 \\
\hline 85. & Riley LH & J Neurosurg & 93 & 46.0 & & Icbg & None & 86.0 \\
\hline 86. & Rosenorn $\mathrm{J}$ & J Neurosurg & 31 & 51.0 & 12.0 & Allo & None & None \\
\hline 87. & Herkowitz HH & Spine & 28 & 42.0 & 50.0 & Icbg & None & 93.0 \\
\hline 88. & Okada K & J Bone Joint Surg Am & 37 & 58.0 & 49.0 & 24 icbg & None & 100.0 \\
\hline 89. & Oterovich JM & J Neurosurg & 37 & & & 14 auto & None & 100.0 \\
\hline 90. & Paramore CG & J Neurosurg & 49 & 47.0 & & 36 icbg 13 fiball plated & None & 100.0 \\
\hline 91. & Dowd CF & J Neurosurg & 40 & 53.0 & 53.0 & Icbg & None & 97.0 \\
\hline 92. & Eleraky MA & J Neurosurg & 185 & 48.2 & 36.0 & $\begin{array}{l}\text { Auto } 141 \\
\text { Allo } 44 \text { all plated }\end{array}$ & None & 99.0 \\
\hline 93. & Majd ME & Spine & 34 & 50.7 & 32.0 & Auto $30 / 34$ plated & None & 97.0 \\
\hline 94. & Thalgott JS & Spine & 26 & 55.0 & 30.0 & Allo all plated & None & 100.0 \\
\hline 95. & Tribus CB & Spine & 16 & 42.1 & 19.2 & Icbg all plated & Fusion scale 1 to 4 & 100.0 \\
\hline 96. & Saunders RL & Spine & 31 & & 24.0 & $\begin{array}{l}17 \text { autofib } \\
14 \text { all fib }\end{array}$ & None & 89.0 \\
\hline 97. & Heidecke V & Spine & 96 & 49.0 & 12.0 & Bariable all plated & None & 100.0 \\
\hline 98. & Madawi AA & Spine & 50 & 50.0 & 17.0 & Icbg & $\mathrm{Bt}$ & 96.0 \\
\hline 99. & Savolainen S & Neurosurgery & 60 & 49.0 & 48.0 & Icbg & $\mathrm{Bt}$ & 100.0 \\
\hline 100. & Chiles BW & Neurosurgery & 76 & 56.0 & 8.9 & Allo 65 auto 11 & None & \\
\hline 101. & Kawakami M & J Spinal Disord & 60 & 51.1 & 54.0 & Icbg & $\mathrm{Fe}$ & 100.0 \\
\hline 102. & Schneeberger AG & J Spinal Disord & 35 & 51.0 & 54.0 & Icbg plated & Bt and fe & 94.0 \\
\hline 103. & Ibanez J & Acta Neurochir & 82 & 51.0 & 17.0 & $\begin{array}{l}\text { Surgibon } 41 \\
\text { Bop } 41\end{array}$ & Bt and fe & $\begin{array}{r}\text { Bop } 9.0 \\
\text { Sur } 38.0\end{array}$ \\
\hline 104. & Yang $\mathrm{K}$ & Clin Orthop Relat Res & es 132 & 50.1 & 47.0 & Icbg & None & 62.9 \\
\hline 105. & Depalma AF & Clin Orthop Relat Res & es 146 & 43 & 27.4 & & $\mathrm{Fe}$ & 89.1 \\
\hline 106. & Bosacco DN & Orthopedics & 232 & 50 & 80.0 & Icbg & None & 89.2 \\
\hline 107. & Bose B & Surg Neurol & 97 & 50.3 & 9.0 & $\begin{array}{l}\text { Allofib } \\
13 \text { icbg } 84 \text { all plated }\end{array}$ & None & 98.0 \\
\hline 108. & Randle MJ & Surg Neurol & 54 & 29.2 & 6.0 & Icbg all plated & None & 100.0 \\
\hline 109. & Yonenobu K & Spine & 50 & 51.4 & 54.0 & Icbg & None & 64.0 \\
\hline 110. & Cabarela ME & Spine & 8 & 24.5 & 36.0 & Icbg plated & None & 100.0 \\
\hline 111. & Green PW & $\mathrm{J}$ Bone Joint Surg Br & 29 & 53.0 & 54.0 & Icbg & None & 82.7 \\
\hline 112. & Martin G & Spine & 289 & & 33.0 & Allofib & $\mathrm{Bt}$ & 88.0 \\
\hline
\end{tabular}

bt/st: bridging/spanning trabeculae, Fe: flexion/extension.

\section{Discussion}

Fusion depends on a variety of factors such as the stability and type of graft, the status of the grafting bed, and the condition of the host. The variance of these can lead to a wide discrepancy in fusion rates following anterior cervical spine surgery. On the other hand, uniformly performed studies utilizing similar procedures, grafts, diagnoses, patient populations and surgical techniques should have fairly uniform fusion rates. Such an assumption can only be tested if the criteria for the determination of fusion are uniform.

We undertook this study to determine if a consensus opinion for fusion exists in the literature.

In the present study, we reviewed a total of 144 articles on anterior cervical fusion in order to determine if there is a consensus on the definition of fusion. As can be seen from the data, no such consensus existed in the earlier literature. However, it appears that a consensus is beginning to emerge 


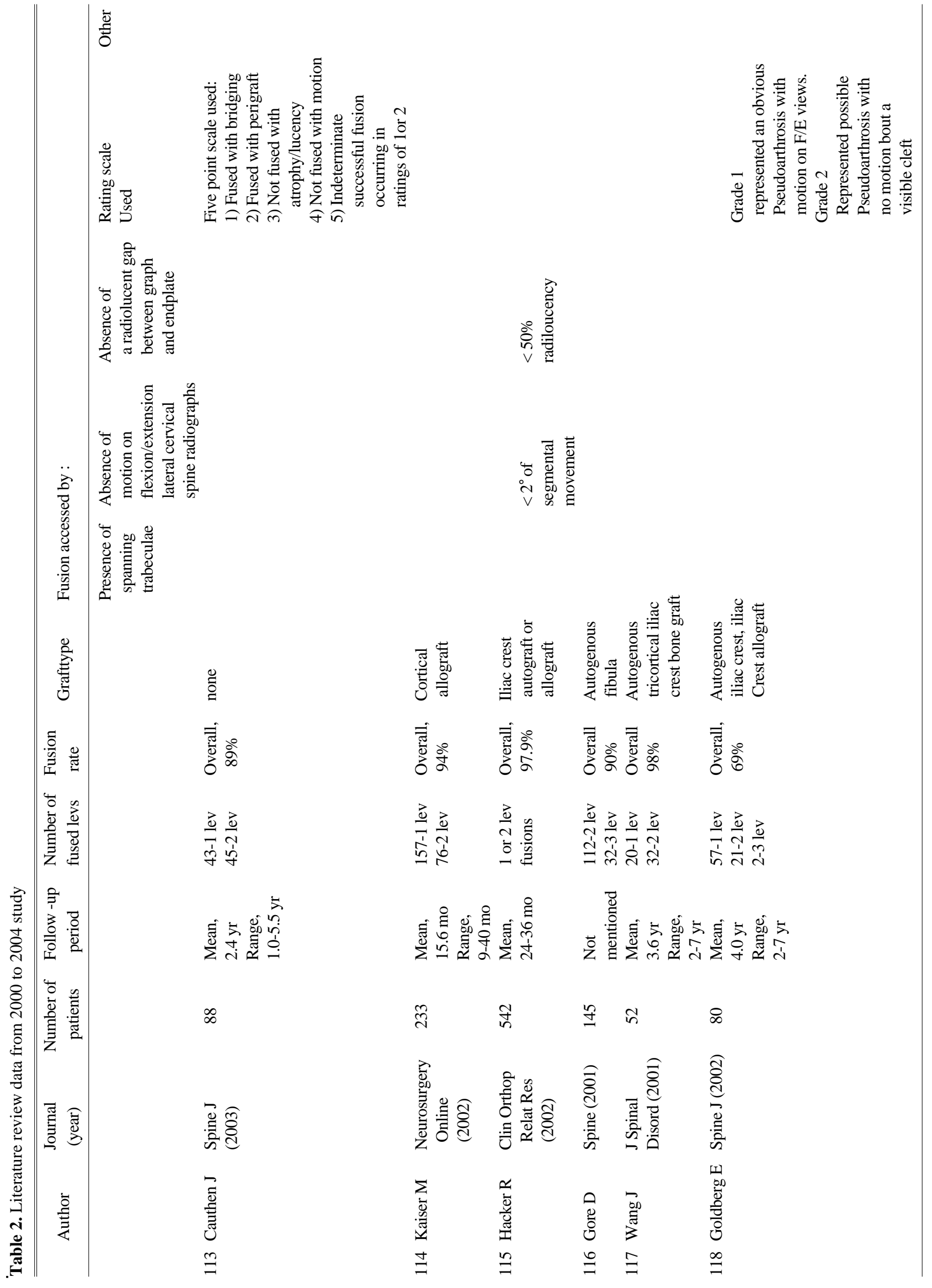




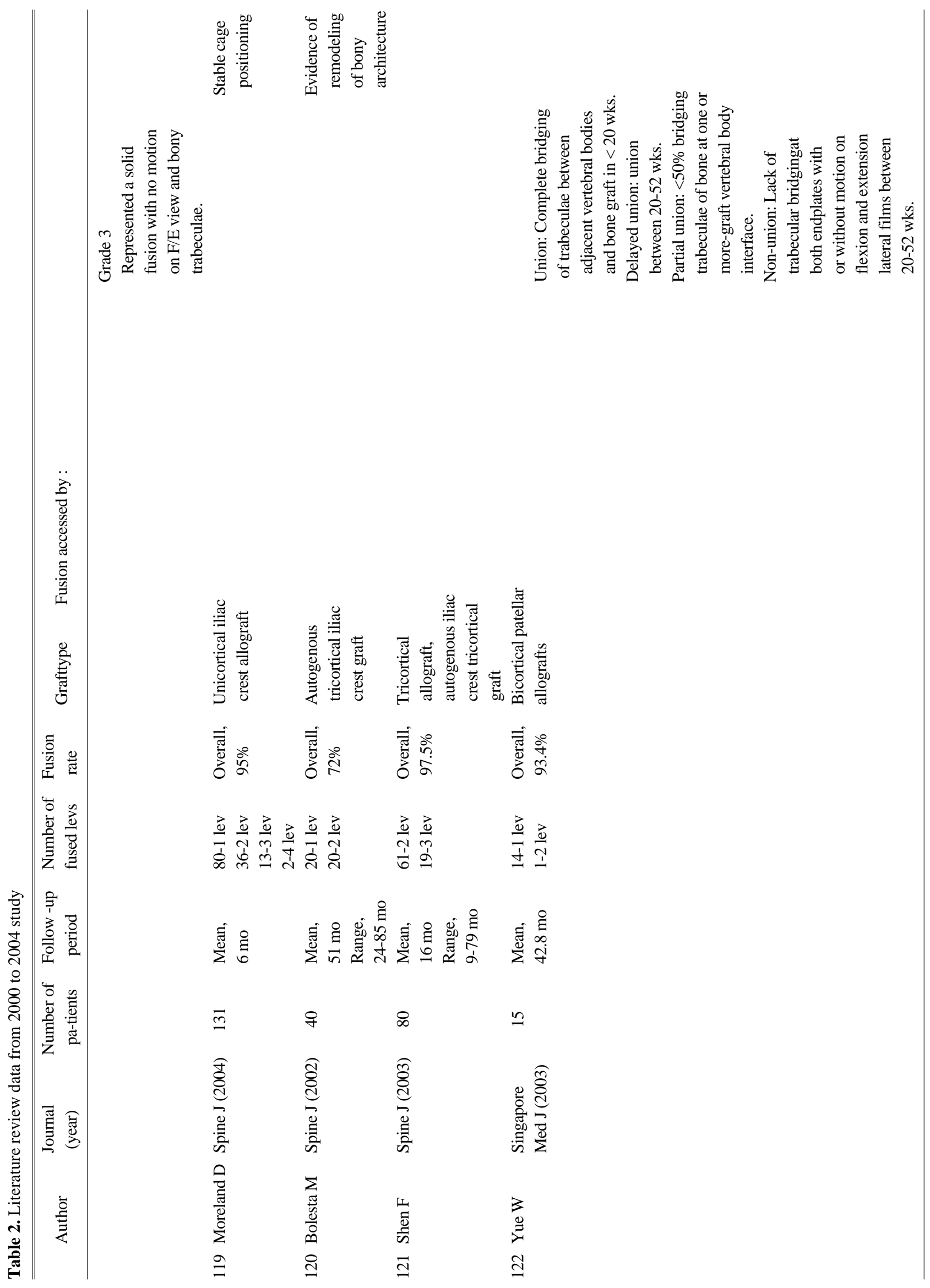




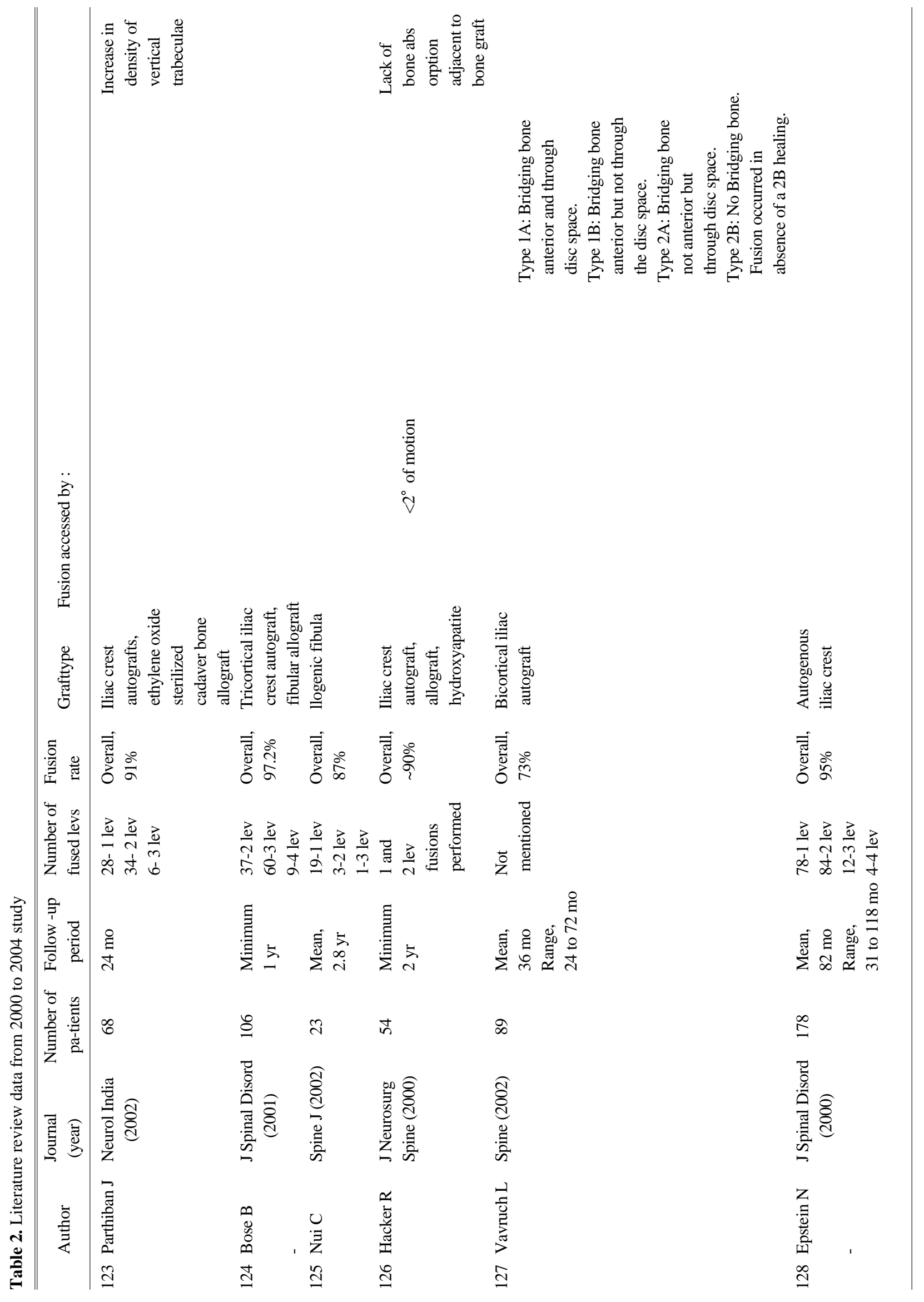




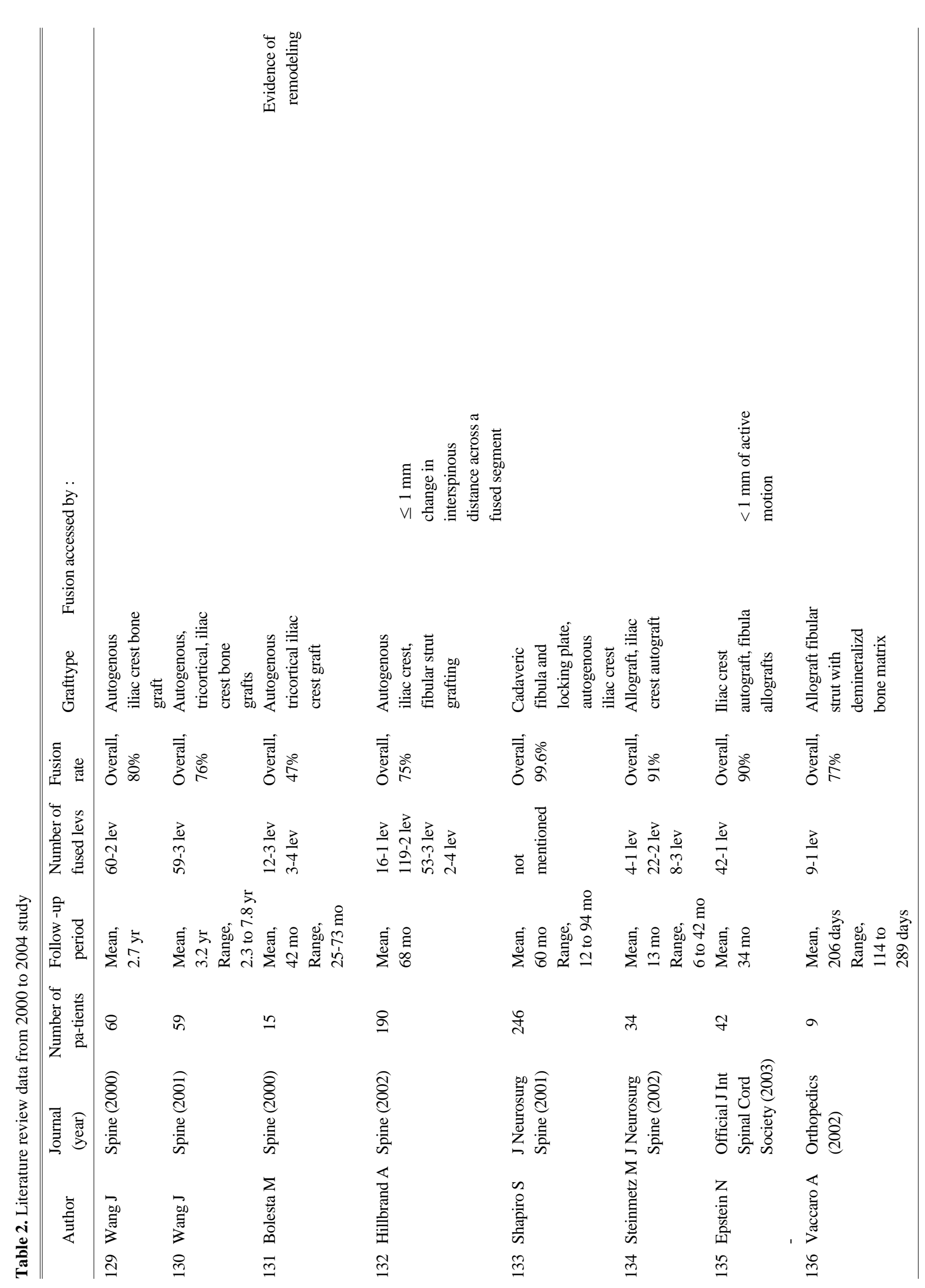




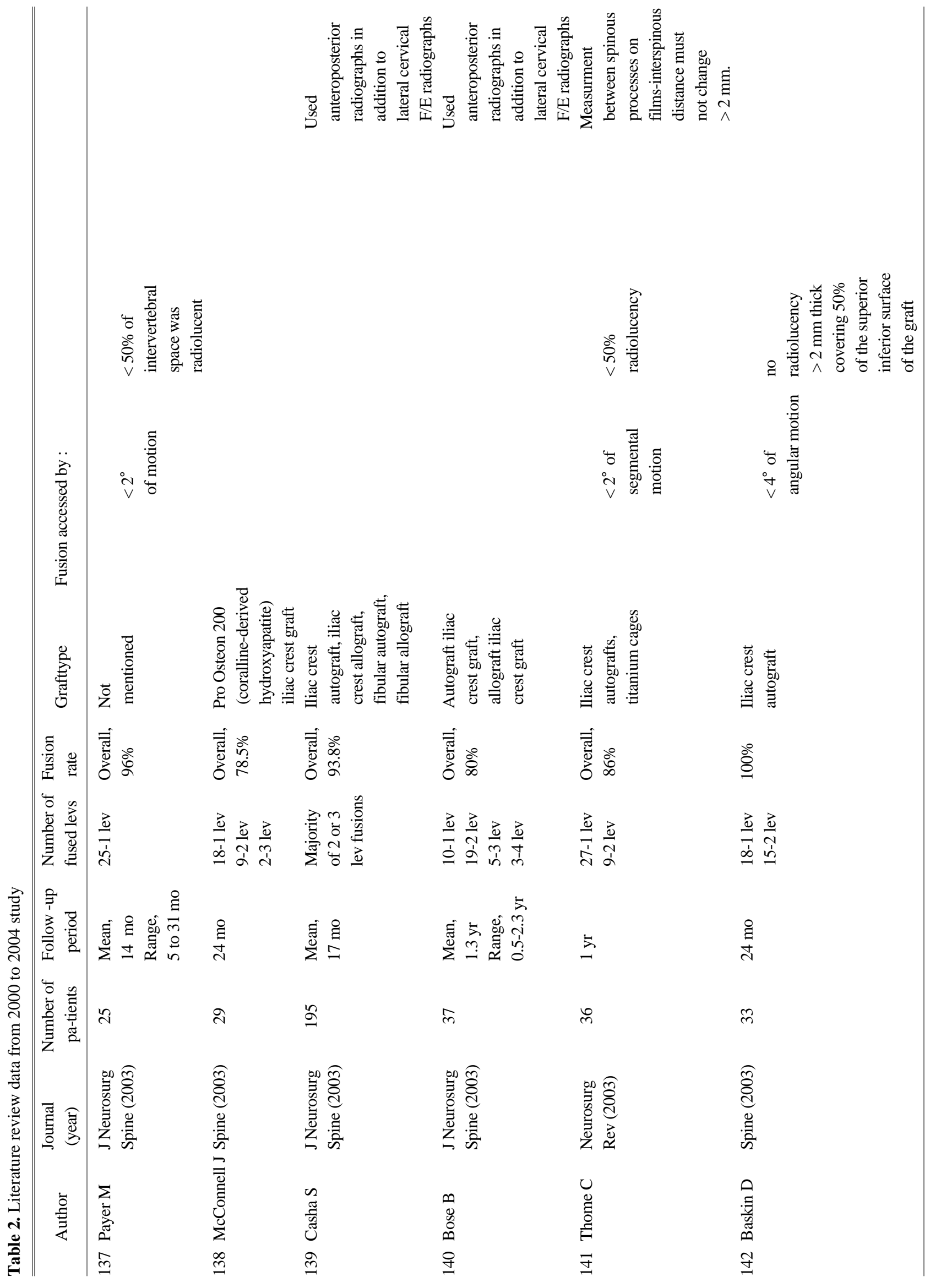




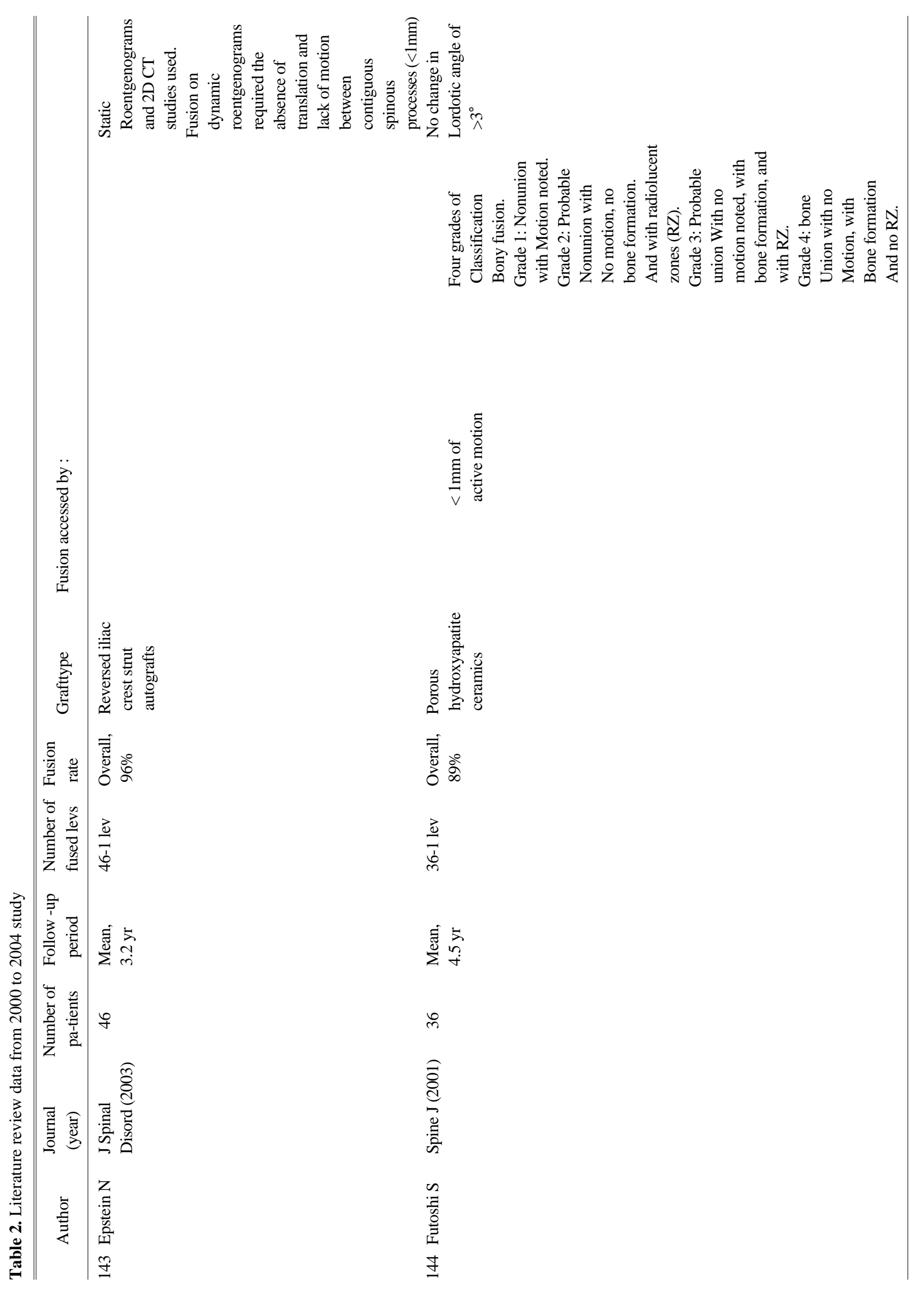


in the newer literature. The majority (63\%) of these later articles utilize the most stringent plain radiographic definition of fusion.

Some studies in our analysis quote very high fusion rates basing their assessment solely on clinical criteria or patients' subjective feelings. Other studies reveal lower fusion rates; however, these studies use more stringent criteria of bridging trabeculae crossing the graft/host interface and absence of motion on dynamic films. What we found most surprising was that more than half of the older articles examining fusion following anterior cervical spine surgery fail to give any definition of fusion. Smith and Robinson in their landmark articles ${ }^{145,146}$, used this more stringent definition of fusion. While there has been a lot of deviation from these criteria over the years, it appears that we are finally returning to the recommendations made fifty years ago.

We are unaware of any studies that have actually examined the accuracy of the various radiographic criteria for assessing fusion. It may be that the presence of bridging trabeculae is more accurate than the absence of motion on flexion/extension views or vice versa. The question also remains as to the interpretation of the fusion status when these two assessment methods disagree. Until a clinicalpathological study is performed where radiographic examination is followed by histological confirmation, it cannot be unequivocally determined which of these two assessment methods is the most accurate.

Nevertheless, we believe that if there are times when a pseudoarthrosis can only be detected on either dynamic or static views, and therefore both are required to confirm the diagnosis.

To date, no study has determined unequivocally if fusion status has any bearing on outcome. Before such studies are undertaken, we need to develop a uniform definition of solid arthrodesis following anterior cervical spine surgery. Further, for meaningful comparisons amongst studies, the measurement tool needs to be uniform. To that end, we recommend that all studies reporting on fusion rates use flexion/extension films in addition to static radiographs. A solid bony arthrodesis can then be based on the presence of both bridging trabeculae and the absence of motion on flexion/extension radiographs.

\section{REFERENCES}

1. Dowd GC, Wirth FP: Anterior cervical discectomy: is fusion necessary? J Neurosurg 1999; 90: 8-12.

2. Majd ME, Vadhva M, Holt RT: Anterior cervical reconstruction using titanium cages with anterior plating. Spine 1999; 15: 1604-1610.

3. Eleraky MA, Llanos C, Sonntag VK: Cervical corpectomy: report of 185 cases and review of the literature. J Neurosurg 1999; 90: 35-41.

4. Thalgott JS, Fritts K, Giuffre JM, Timlin M: Anterior interbody fusion of the cervical spine with coralline hydroxyapatite. Spine 1999; 13: 1295-1299.

5. Tribus CB, Corteen DP, Zdeblick TA: The efficacy of anterior cervical plating in the management of symptomatic pseudoarthrosis of the cervical spine. Spine 1999; 9: 860-864.

6. Saunders RL, Pikus HJ, Ball P: Four-level cervical corpectomy. Spine 1998; 22: 2455-2461.

7. Heidecke V, Rainov NG, Burkert W: Anterior cervical fusion with the Orion locking plate system. Spine 1998; 16: 1796-1802.

8. Madawi AA, Powell M, Crockard HA: Biocompatible osteoconductive polymer versus iliac graft. A prospective comparative study for the evaluation of fusion pattern after anterior cervical discectomy. Spine 1996; 18: 21232129.

9. Otero Vich JM: Anterior cervical interbody fusion with threaded cylindrical bone. J Neurosurg 1985; 63: 750753.

10. Paramore CG, Dickman CA, Sonntag VK: Radiographic and clinical follow-up review of Caspar plates in 49 patients. J Neurosurg 1996; 84: 957-961.

11. Wetzel FT, Hoffman MA, Arcieri RR: Freeze-dried fibular allograft in anterior spinal surgery: cervical and lumbar applications. Yale J Biol Med 1993; 66: 263-275.

12. Mutoh N, Shinomiya K, Furuya K, Yamaura I, Satoh H: Pseudarthrosis and delayed union after anterior cervical fusion. Int Orthop 1993; 17: 286-289.

13. Okada K, Shirasaki N, Hayashi H, Oka S, Hosoya T: Treatment of cervical spondylotic myelopathy by enlargement of the spinal canal anteriorly, followed by arthrodesis. J Bone Joint Surg Am 1991; 73: 352-364.

14. Riley LH Jr, Robinson RA, Johnson KA, Walker AE: The results of anterior interbody fusion of the cervical spine. Review of ninety-three consecutive cases. J Neurosurg 1969; 30: 127-133.

15. Rosenorn J, Hansen EB, Rosenorn MA: Anterior cervical discectomy with and without fusion. A prospective study. J Neurosurg 1983; 59: 252-255. 
16. Herkowitz HN, Kurz LT, Overholt DP: Surgical management of cervical soft disc herniation. A comparison between the anterior and posterior approach. Spine 1990; 10: $1026-1030$.

17. Baba H, Furusawa N, Chen Q, Imura S, Tomita K: Anterior decompressive surgery for cervical ossified posterior longitudinal ligament causing myeloradiculopathy. Paraplegia 1995; 33: 18-24.

18. Ebraheim NA, DeTroye RJ, Rupp RE, Taha J, Brown J, Jackson WT: Osteosynthesis of the cervical spine with an anterior plate. Orthopedics 1995; 2: 141-147.

19. Isu T, Minoshima S, Mabuchi S: Anterior decompression and fusion using bone grafts obtained from cervical vertebral bodies for ossification of the posterior longitudinal ligament of the cervical spine: technical note. Neurosurgery 1997; 4: 866-869.

20. Katsuura A, Hukuda S, Imanaka T, Miyamoto K, Kanemoto M: Anterior cervical plate used in degenerative disease can maintain cervical lordosis. J Spinal Disord 1996; 6: 470-476.

21. Seifert V, Stolke D: Multisegmental cervical spondylosis: treatment by spondylectomy, microsurgical decompression, and osteosynthesis. Neurosurgery 1991; 4: 498-503.

22. Shapiro SA, Snyder W: Spinal instrumentation with a low complication rate. Surg Neurol 1997; 48: 566-574.

23. Deburge A, Mazda K, Guigui P: Unstable degenerative spondylolisthesis of the cervical spine. J Bone Joint Surg Br 1995; 1: 122-125.

24. Zdeblick TA, Hughes SS, Riew KD, Bohlman HH: Failed anterior cervical discectomy and arthrodesis. Analysis and treatment of thirty-five patients. J Bone Joint Surg Am 1997; 4: 523-532.

25. Tominaga T, Koshu K, Mizoi K, Yoshimoto T: Anterior cervical fixation with the titanium locking screw-plate: a preliminary report. Surg Neurol 1994; 42: 408-413.

26. Shapiro S: Banked fibula and the locking anterior cervical plate in anterior cervical fusions following cervical discectomy. J Neurosurg 1996; 84: 161-165.

27. Johnston FG, Crockard HA: One-stage internal fixation and anterior fusion in complex cervical spinal disorders. $\mathbf{J}$ Neurosurg 1995; 82: 234-238.

28. Herman JM, Sonntag VK: Cervical corpectomy and plate fixation for postlaminectomy kyphosis. J Neurosurg 1994; 80: 963-970.

29. Isu T, Kamada K, Kobayashi N, Mabuchi S: The surgical technique of anterior cervical fusion using bone grafts obtained from cervical vertebral bodies. J Neurosurg
1994; 80: 16-19.

30. Macdonald RL, Fehlings MG, Tator CH, et al: Multilevel anterior cervical corpectomy and fibular allograft fusion for cervical myelopathy. J Neurosurg 1997; 86: 990-997.

31. Coric D, Branch CL Jr, Jenkins JD: Revision of anterior cervical pseudoarthrosis with anterior allograft fusion and plating. J Neurosurg 1997; 86: 969-974.

32. Bishop RC, Moore KA, Hadley MN: Anterior cervical interbody fusion using autogeneic allogeneic bone graft substrate: a prospective comparative analysis. J Neurosurg 1996; 85: 206-210.

33. Connolly PJ, Esses SI, Kostuik JP: Anterior cervical fusion: outcome analysis of patients fused with and without anterior cervical plates. J Spinal Disord 1996; 3: 202206.

34. Goffin J, van Loon J, Van Calenbergh F, Plets C: Long-term results after anterior cervical fusion and osteosynthetic stabilization for fractures and/or dislocations of the cervical spine. J Spinal Disord 1995; 6: 500508.

35. McGuire RA, St John K: Comparison of anterior cervical fusions using autogenous bone graft obtained from the cervical vertebrae to the modified Smith-Robinson technique. J Spinal Disord 1994; 6: 499-503.

36. Chang KW, Lin GZ, Liu YW, Suen KL, Liang PL: Intraosseous screw fixation of anterior cervical graft construct after diskectomy. J Spinal Disord 1994; 2: 126-129.

37. Iwasaki M, Okada K, Tsumaki N, Obata H, Shirasaki N, Oka S: Cervical spondylotic radiculopathy involving two adjacent nerve roots. Anterior decompression through a single level intervertebral approach. Int Orthop 1996; 20: 137-141.

38. Naito M, Kurose S, Oyama M, Sugioka Y: Anterior cervical fusion with the Caspar instrumentation system. Int Orthop 1993; 17: 73-76.

39. Harsh GR 4th, Sypert GW, Weinstein PR, Ross DA, Wilson CB: Cervical spine stenosis secondary to ossification of the posterior longitudinal ligament. J Neurosurg 1987; 67: 349-357.

40. Kadoya S, Nakamura T, Kwak R, Hirose G: Anterior osteophytectomy for cervical spondylotic myelopathy in developmentally narrow canal. J Neurosurg 1985; 63: 845-850.

41. Aronson N, Filtzer DL, Bagan M: Anterior cervical fusion by the smith-robinson approach. J Neurosurg 1968; 29: $397-404$ 
42. Connolly ES, Seymour RJ, Adams JE: Clinical evaluation of anterior cervical fusion for degenerative cervical disc disease. J Neurosurg 1965; 23: 431-437.

43. Siqueira EB, Kranzler LI: Cervical interbody fusion using calf bone. Surg Neurol 1982; 18: 37-39.

44. Zhang ZH, Yin H, Yang K, et al: Anterior intervertebral disc excision and bone grafting in cervical spondylotic myelopathy. Spine 1983; 1: 16-19.

45. Kadoya S, Nakamura T, Kwak R: A microsurgical anterior osteophytectomy for cervical spondylotic myelopathy. Spine 1984; 5: 437-441.

46. Mann DC, Bruner BW, Keene JS, Levin AB: Anterior plating of unstable cervical spine fractures. Paraplegia 1990; 28: 564-572.

47. Kostuik JP, Connolly PJ, Esses SI, Suh P: Anterior cervical plate fixation with the titanium hollow screw plate system. Spine 1993; 10: 1273-1278.

48. Caspar W, Geisler FH, Pitzen T, Johnson TA: Anterior cervical plate stabilization in one-and two-level degenerative disease: overtreatment or benefit? J Spinal Disord 1998; 1: 1-11.

49. Ou Y, Lu J, Mi J, et al: Extensive anterior decompression for mixed cervical spondylosis. Resection of uncovertebral joints, neural and transverse foraminotomy, subtotal corpectomy, and fusion with strut graft. Spine 1994: 23: 2651-2656.

50. Ripa DR, Kowall MG, Meyer PR Jr, Rusin JJ: Series of ninety-two traumatic cervical spine injuries stabilized with anterior ASIF plate fusion technique. Spine 1991; 3 : S46-55.

51. Clements DH, O'Leary PF: Anterior cervical discectomy and fusion. Spine 1990; 10: 1023-1025.

52. Muhlbauer M, Saringer W, Aichholzer M, SunderPlassmann M: Microsurgical anterior decompression and internal fixation with iliac bone graft and titanium plates for treatment of cervical intervertebral disc herniation. Acta Neurochir 1995; 134: 207-213.

53. Krag MH, Robertson PA, Johnson CC, Stein AC: Anterior cervical fusion using a modified tricortical bone graft: a radiographic analysis of outcome. J Spinal Disord 1997; 5: 420-430.

54. Savolainen S, Usenius JP, Hernesniemi J: Iliac crest versus artificial bone grafts in 250 cervical fusions. Acta Neurochir 1994; 129: 54-57.

55. Matge G: Anterior interbody fusion with the BAK-cage in cervical spondylosis. Acta Neurochir 1998; 140: 1-8.

56. Moerman J, Harth A, Van Trimpont I, et al: Treatment of unstable fractures, dislocations and fracture-dislocations of the cervical spine with Senegas plate fixation. Acta Orthop Belg 1994; 1: 30-35.

57. Schnee CL, Freese A, Weil RJ, Marcotte PJ: Analysis of harvest morbidity and radiographic outcome using autograft for anterior cervical fusion. Spine 1997; 19: 2222-2227.

58. Phillips FM, Carlson G, Emery SE, Bohlman HH: Anterior cervical pseudoarthrosis. Natural history and treatment. Spine 1997; 14: 1585-1589.

59. Hilibrand AS, Yoo JU, Carlson GD, Bohlman HH: The success of anterior cervical arthrodesis adjacent to a previous fusion. Spine 1997; 14: 1574-1579.

60. Malca SA, Roche PH, Rosset E, Pellet W: Cervical interbody xenograft with plate fixation. evaluation of fusion after 7 years of use in post-traumatic discoligamentous instability. Spine 1996; 6: 685-690.

61. Lowery GL, Swank ML, McDonough RF: Surgical revision for failed anterior cervical fusions. Articular pillar plating or anterior revision? Spine 1995; 22: 2436 2441.

62. An HS, Simpson JM, Glover JM, Stephany J: Comparison between allograft plus demineralized bone matrix versus autograft in anterior cervical fusion. A prospective multicenter study. Spine 1995; 20: 2211-2216.

63. Brigham CD, Tsahakis PJ: Anterior cervical foraminotomy and fusion. Surgical technique and results. Spine 1995; 7: 766-770.

64. Villas C, Martinez-Peric R, Preite R, Barrios RH: Union after multiple anterior cervical fusion. 21 cases followed for 1-6 years. Acta Orthop Scand 1994; 65: 620622

65. Cauthen JC, Kinard RE, Vogler JB, et al: Outcome analysis of noninstrumented anterior cervical discectomy and interbody fusion in 348 patients. Spine 1998; 2: 188192

66. Emery SE, Fisher JR, Bohlman HH: Three-level anterior cervical discectomy and fusion: radiographic and clinical results. Spine 1997; 22: 2622-2624.

67. Watters WC 3rd, Levinthal R: Anterior cervical discectomy with and without fusion. Results, complications, and long-term follow-up. Spine 1994; 20: 2343-2347.

68. Emery SE, Bolesta MJ, Banks MA, Jones PK: Robinson anterior cervical fusion comparison of the standard and modified techniques. Spine 1994; 6: 660-663.

69. Capen DA, Garland DE, Waters RL: Surgical stabilization of the cervical spine. A comparative analysis of ante- 
riorand posterior spine fusions. Clin Orthop Relat Res 1985; 196: 229-237.

70. Doi K, Kawai S, Sumiura S, Sakai K: Anterior cervical fusion using the free vascularized fibular graft. Spine 1988; 11: 1239-1244.

71. Herkowitz HN: A comparison of anterior cervical fusion, cervical laminectomy, and cervical laminoplasty for the surgical management of multiple level spondylotic radiculopathy. Spine 1988; 7: 774-780.

72. Brown JA, Havel P, Ebraheim N, Greenblatt SH, Jackson WT: Cervical stabilization by plate and bone fusion. Spine 1988; 3: 236-240.

73. Gore DR, Sepic SB: Anterior cervical fusion for degenerated or protruded discs. A review of one hurdred forty-six patients. Spine 1984; 7: 667-671.

74. Zdeblick TA, Bohlman HH: Cervical kyphosis and myelopathy. Treatment by anterior corpectomy and strutgrafting. J Bone Joint Surg Am 1989; 71: 170-182.

75. Jacobs B, Krueger EG, Leivy DM: Cervical spondylosis with radiculopathy. Results of anterior diskectomy and interbody fusion. JAMA 1970; 13: 2135-2139.

76. Anderson LD, Stivers BR, Park WI 3rd: Multiple level anterior cervical spine fusion. A report of 16 cases. J Trauma 1974: 8: 653-674.

77. Tunturi T, Leikkonen O, Paakkala T, Lepisto P, Rokkanen P: Cloward's anterior fusion in the treatment of cervical spinal traumatic injury and degeneration. Arch Orthop Trauma Surg 1979; 94: 1-9.

78. De Palma AF, Cooke AJ: Results of anterior interbody fusion of the cervical spine. Clin Orthop Relat Res 1968; 60: $169-185$.

79. Brown MD, Malinin TI, Davis PB: A roentgenographic evaluation of frozen allografts versus autografts in anterior cervical spine fusions. Clin Orthop Relat Res 1976; 19: 231-236.

80. Fielding JW, Lusskin R, Batista A: Multiple segment anterior cervical spinal fusion. Clin Orthop Relat Res 1967; 54: 29-33.

81. Kambin P: Anterior cervical fusion using vertical selflocking T-graft. Clin Orthop Relat Res 1980; 153: 132137.

82. Gore DR: Technique of cervical interbody fusion. Clin Orthop Relat Res 1984; 188: 191-195.

83. Brunton FJ, Wilkinson JA, Wise KS, Simonis RB: Cine radiography in cervical spondylosis as a means of determining the level for anterior fusion. J Bone Joint Surg Br 1982; 64: 399-404.
84. Simmons EH, Bhalla SK: Anterior cervical discectomy and fusion. A clinical and biomechanical study with eight-year follow-up. J Bone Joint Surg Br 1969; 51: 225237.

85. Tippets RH, Apfelbaum RI: Anterior cervical fusion with the Caspar instrumentation system. Neurosurgery 1988; 22: 1008-1013.

86. Kojima T, Waga S, Kubo Y, Kanamaru K, Shimosaka S, Shimizu T: Anterior cervical vertebrectomy and interbody fusion for multi-level spondylosis and ossification of the posterior longitudinal ligament. Neurosurgery 1989; 24: 864-872.

87. Young WF, Rosenwasser RH: An early comparative analysis of the use of fibular allograft versus autologous iliac crest graft for interbody fusion after anterior cervical discectomy. Spine 1993; 18: 1123-1124.

88. Brodke DS, Zdeblick TA: Modified Smith-Robinson procedure of anterior cervical discectomy and fusion. Spine 1992; 17: S427-430.

89. Brodsky AE, Khalil MA, Sassard WR, Newman BP: Repair of symptomatic pseudoarthrosis of anterior cervical fusion. Posterior versus anterior repair. Spine 1992; 17: 1137-1143.

90. Zdeblick TA, Ducker TB: The use of freeze-dried allograft bone for anterior cervical fusions. Spine 1991; 16: 726-729.

91. Grossman W, Peppelman WC, Baum JA, Kraus DR: The use of freeze-dried fibular allograft in anterior cervical fusion. Spine 1992; 17: 565-569.

92. Suh PB, Kostuik JP, Esses SI: Anterior cervical plate fixation with the titanium hollow screw plate system. A preliminary report. Spine 1990; 15: 1079-1081.

93. Kozak JA, Hanson GW, Rose JR, Trettin DM, Tullos HS: Anterior discectomy, microscopic decompression, and fusion: a treatment for cervical spondylotic radiculopathy. J Spinal Disord 1989; 2: 43-46.

94. Shinomiya K, Okamoto A, Kamikozuru M, Furuya K, Yamaura I: An analysis of failures in primary cervical anterior spinal cord decompression and fusion. J Spinal Disord 1993; 6: 277-288.

95. Lindberg L: Anterior cervical fusion for cervical rhizopathies. A follow-up study. Acta Orthop Scand 1970; 41: 312-319.

96. Svendgaard N, Cronqvist S, Delgado T, Salford LG: Treatment of severe cervical spine injuries by anterior interbody fusion with early mobilization. Acta Neurochir 1982; 60: 91-105. 
97. White AA 3rd, Southwick WO, Deponte RJ, Gainor JW, Hardy R: Relief of pain by anterior cervical-spine fusion for spondylosis. A report of sixty-five patients. J Bone Joint Surg Am. 1973; 55: 525-534.

98. Green PW: Anterior cervical fusion. A review of thirtythree patients with cervical disc degeneration. J Bone Joint Surg Br 1977; 59: 236-240.

99. Cabanela ME, Ebersold MJ: Anterior plate stabilization for bursting teardrop fractures of the cervical spine. Spine 1988; 13: 888-891.

100. Yonenobu K, Fuji T, Ono K, Okada K, Yamamoto T, Harada N: Choice of surgical treatment for multisegmental cervical spondylotic myelopathy. Spine 1985; 10: 710716.

101. Randle MJ, Wolf A, Levi L, et al: The use of the anterior Caspar plate fixation in acute cervical spine injury. Surg Neurol 1991; 36: 181-189.

102. Bose B: Anterior cervical fusion using Caspar plating: analysis of results and review of the literature. Surg Neurol 1998; 49: 25-31.

103. Martin G, Haid RW Jr, MacMillan M, Rodts GE Jr, Berkman R: Anterior cervical discectomy with freezedried fibula allograft. Overview of 317 cases and literature review. Spine 1999; 24: 852-858.

104. Bosacco DN, Berman AT, Levenberg RJ, Bosacco SJ: Surgical results in anterior cervical discectomy and fusion using a countersunk interlocking autogenous iliac bone graft. Orthopedics 1992; 15: 923-925.

105. De Palma AF, Cooke AJ: Results of anterior interbody fusion of the cervical spine. Clin Orthop Relat Res 1968; 60: 169-185.

106. Yang KC, Lu XS, Cai QL, Ye LX, Lu WQ: Cervical spondylotic myelopathy treated by anterior multilevel decompression and fusion. Follow-up report of 214 cases. Clin Orthop Relat Res 187; 221: 161-164.

107. Ibanez J, Carreno A, Garcia-Amorena C, Caral J, Gaston F, Ferrer E: Results of the biocompatible osteoconductive polymer (BOP) as an intersomatic graft in anterior cervical surgery. Acta Neurochir 1998; 140: 126-133.

108. Schneeberger AG, Boos N, Schwarzenbach O, Aebi M: Anterior cervical interbody fusion with plate fixation for chronic spondylotic radiculopathy: a 2-to 8-year followup. J Spinal Disord 1999; 12: 215-220.

109. Kawakami M, Tamaki T, Yoshida M, Hayashi N, Ando M, Yamada H: Axial symptoms and cervical alignments after cervical anterior spinal fusion for patients with cervical myelopathy. J Spinal Disord 1999;
12: 50-56.

110. Chiles BW 3rd, Leonard MA, Choudhri HF, Cooper PR: Cervical spondylotic myelopathy: patterns of neurological deficit and recovery after anterior cervical decompression. Neurosurgery 1999; 44: 762-769.

111. Savolainen S, Rinne J, Hernesniemi J: A prospective randomized study of anterior single-level cervical disc operations with long-term follow-up: surgical fusion is unnecessary. Neurosurgery 1998; 43: 51-55.

112. Boccanera L, Laus M: Osteosynthesis of the cervical spine with an anterior plate. Ital J Orthop Traumatol 1989; 15: 287-294.

113. Kaiser M, Haid R, Subach B, Barnes B, Rodts G: Anterior Cervical Plating Enhances Arthrodesis after Discectomy and Fusion with Cortical Allograft. Neurosurgery 2002; 50: 229-238.

114. Hacker RJ: Threaded cages for degenerative cervical disease. Clin Orthop Relat Res 2002; 394: 39-46.

115. Gore DR: The arthrodesis rate in multilevel anterior cervical fusions using autogenous fibula. Spine 2001; 26: 1259-1263.

116. Wang JC, McDonough PW, Endow KK, Delamarter RB: A comparison of fusion rates between single-level cervical corpectomy and two-level discectomy and fusion. J Spinal Disord 2001; 14: 222-225.

117. Goldberg EJ, Singh K, Van U, Garretson R, An HS: Comparing outcomes of anterior cervical discectomy and fusion in workman's versus non-workman's compensation population. Spine J 2002; 2: 408-414

118. Moreland DB, Asch HL, Clabeaux DE, et al: Anterior cervical discectomy and fusion with implantable titanium cage: initial impressions, patient outcomes and comparison to fusion with allograft. Spine J 2004; 4: 184-191.

119. Bolesta MJ, Rechtine GR 2nd, Chrin AM: One-and two-level anterior cervical discectomy and fusion: the effect of plate fixation. Spine J 2002; 2: 197-203.

120. Samartzis D, Shen FH, Matthews DK, Yoon ST, Goldberg EJ, An HS: Comparison of allograft to autograft in multilevel anterior cervical discectomy and fusion with rigid plate fixation. Spine J 2003; 3: 451-459.

121. Yue WM, Tay BK, Kasinathan ST: Patellar allografts in anterior cervical fusion - a two-year clinical and radiographic study. Singapore Med J 2003; 44: 521-525.

122. Parthiban JK, Singhania BK, Ramani PS: A radiological evaluation of allografts (ethylene oxide sterilized cadaver bone) and autografts in anterior cervical fusion. Neurol India 2002; 50: 17-22. 
123. Bose B: Anterior cervical instrumentation enhances fusion rates in multilevel reconstruction in smokers. $\mathbf{J}$ Spinal Disord 2001; 14: 3-9.

124. Niu CC, Hai Y, Fredrickson BE, Yuan HA: Anterior cervical corpectomy and strut graft fusion using a different method. Spine J 2002; 2: 179-187.

125. Hacker RJ: A randomized prospective study of an anterior cervical interbody fusion device with a minimum of 2 years of follow-up results. J Neurosurg 2000; 93: 222226.

126. Vavruch L, Hedlund R, Javid D, Leszniewski W, Shalabi A: A prospective randomized comparison between the cloward procedure and a carbon fiber cage in the cervical spine: a clinical and radiologic study. Spine 2002; 27: 1694-1701.

127. Epstein NE: Anterior cervical diskectomy and fusion without plate instrumentation in 178 patients. J Spinal Disord 2000; 13: 1-8.

128. Wang JC, McDonough PW, Endow KK, Delamarter RB: Increased fusion rates with cervical plating for twolevel anterior cervical discectomy and fusion. Spine 2000; 25: 41-45.

129. Wang JC, McDonough PW, Kanim LE, Endow KK, Delamarter RB: Increased fusion rates with cervical plating for three-level anterior cervical discectomy and fusion. Spine 2001; 26: 643-646.

130. Bolesta MJ, Rechtine GR 2nd, Chrin AM: Three-and four-level anterior cervical discectomy and fusion with plate fixation: a prospective study. Spine 2000; 25: 20402046.

131. Hilibrand AS, Fye MA, Emery SE, Palumbo MA, Bohlman HH: Increased rate of arthrodesis with strut grafting after multilevel anterior cervical decompression. Spine 2002; 27: 146-151.

132. Thome C, Krauss JK, Zevgaridis D: A prospective clinical comparison of rectangular titanium cages and iliac crest autografts in anterior cervical discectomy and fusion. Neurosurg Rev 2004; 27: 34-41.

133. Baskin DS, Ryan P, Sonntag V, Westmark R, Widmayer MA: A prospective, randomized, controlled cervical fusion study using recombinant human bone morphogenetic protein-2 with the CORNERSTONE-SR allograft ring and the ATLANTIS anterior cervical plate. Spine 2003; 28: 1219-1224.

134. Epstein NE, Silvergleide RS: Documenting fusion following anterior cervical surgery: a comparison of roentgenogram versus two-dimensional computed tomo- graphic findings. J Spinal Disord Tech 2003; 16: 243-247.

135. Suetsuna F, Yokoyama T, Kenuka E, Harata S: Anterior cervical fusion using porous hydroxyapatite ceramics for cervical disc herniation. a two-tear follow-up. Spine $\mathbf{J}$ 2001; 1: 348-357.

136. Vaccaro AR, Venger BH, Kelleher PM, et al: Use of a bioabsorbable anterior cervical plate in the treatment of cervical degenerative and traumatic disk disruption. Orthopedics 2002; 25: s1191-1199.

137. Payer M, May D, Reverdin A, Tessitore E: Implantation of an empty carbon fiber composite frame cage after single-level anterior cervical discectomy in the treatment of cervical disc herniation: preliminary results. J Neurosurg 2003; 98: 143-148.

138. Cauthen JC, Theis RP, Allen AT: Anterior cervical fusion: a comparison of cage, dowel and dowel-plate constructs. Spine J 2003; 3: 106-117.

139. McConnell JR, Freeman BJ, Debnath UK, Grevitt MP, Prince HG, Webb JK: A prospective randomized comparison of coralline hydroxyapatite with autograft in cervical interbody fusion. Spine 2003; 28: 317-323.

140. Casha S, Fehlings MG: Clinical and radiological evaluation of the Codman semiconstrained load-sharing anterior cervical plate: prospective multicenter trial and independent blinded evaluation of outcome. J Neurosurg 2003; 99: $264-270$.

141. Bose B: Anterior cervical arthrodesis using DOC dynamic stabilization implant for improvement in sagittal angulation and controlled setting. J Neurosurg 2003; 98: 8-13.

142. Steinmetz MP, Warbel A, Whitfield M, Bingaman W: Preliminary experience with the DOC dynamic cervical implant for the treatment of multilevel cervical spondylosis. J Neurosurg 2002; 97: 330-336.

143. Shapiro S, Connolly P, Donnaldson J, Abel T: Cadaveric fibula, locking plate, and allogeneic bone matrix for anterior cervical fusions after cervical discectomy for radiculopathy or myelopathy. J Neurosurg 2001; 95: 43-50.

144. Epstein NE: Anterior cervical dynamic ABC plating with single level corpectomy and fusion in forty-two patients. Spinal Cord 2003; 41: 153-158.

145. Smith GW, Robinson RA: The treatment of certain cervical-spine disorders by the anterior removal of the intervertebral disc and interbody fusion. J Bone Joint Surg Am 1958; 40: 607-624.

146. Robinson RA, Smith GW: Anterolateral cervical disc removal and interbody fusion for cervical disc syndrome. Bull Johns Hopkins Hosp 1955; 96: 223. 